\title{
An examination of the factors affecting consumer's purchase decision in the Malaysian retail market
}

\author{
Jalal Rajeh Hanaysha
}

Faculty of Business and Management, DRB-HICOM University of Automotive Malaysia, Pekan, Malaysia

Received 2 August 2017 Revised 11 October 2017 Accepted 25 October 2017

\begin{abstract}
Purpose - The purpose of this paper is to examine the effects of corporate social responsibility, social media marketing, sales promotion, store environment and perceived value on a purchase decision in the retail sector.

Design/methodology/approach - A quantitative research methodology was used and the data were collected from 278 customers of retail stores in Malaysia. The collected data were analysed using SPSS 19 and structural equation modelling on AMOS.

Findings - The findings showed that corporate social responsibility has significant positive effects on a purchase decision, whereas sales promotion has a negative effect on purchase decision. The outcomes of this study also indicated that store environment has a significant positive effect on consumers' purchase decisions. Contrary to expectations, the findings revealed that the effect of social media marketing on purchase decision is insignificant. Finally, the results showed that perceived value has a significant positive effect on a purchase decision.
\end{abstract}

Originality/value - The findings of this study contribute to an understanding of the importance of the selected factors in affecting a consumer's purchase decision in the retail industry.

Keywords CSR, Purchase decision, Sales promotion, Perceived value, Social media marketing, Store environment

Paper type Research paper

\section{Introduction}

In today's continuously changing and dynamic business environment, it has become necessary for retail managers to clearly understand and foresee how different types of consumers behave when buying different products and services to fulfil their needs. Thus, to establish a competitive advantage in the marketplace, several retailers have focused on creating favourable images about their brands in the minds of consumers to influence their purchase behaviour (Shamsher, 2015). Consumer behaviour emphasizes on understanding the purchase decision process of individual consumers and how they utilize their existing resources such as time, money and effort to get a product or service

(C) Jalal Rajeh Hanaysha. Published in the PSU Research Review: An International Journal. Published by Emerald Publishing Limited. This article is published under the Creative Commons Attribution (CC BY 4.0) licence. Anyone may reproduce, distribute, translate and create derivative works of this article (for both commercial and non-commercial purposes), subject to full attribution to the original publication and authors. The full terms of this licence may be seen at http://creativecommons.org/ licences/by/4.0/legalcode

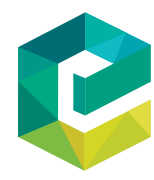

PSU Research Review Vol. 2 No. 1, 2018 pp. 7-23 Emerald Publishing Limited
2399-1747 DOI 10.1108/PRR-08-2017-0034 
PRR

2,1

(Schiffman and Kanuk, 2007). Hence, retail managers should have knowledge about consumers' characteristics and preferences as they play an important role in forming purchase decisions. This information could enable them to foster their competitiveness and ensure their long-term survival.

The consumer decision-making process can be described as the phases that consumers go through in making a final purchase decision. The task of a marketer is to focus on the whole purchasing process instead of emphasizing solely on a purchase decision, because consumers experience different phases before reaching a conclusion (Basil et al., 2013). Understanding buyer behaviour is not easy because several factors can influence consumer behaviour before making a purchase decision. In some cases, consumers tend to spend less time in thinking about purchasing either low- or high-value products, because they consider that fulfilling their needs is more important. This has urged marketing managers to adopt strategies that motivate consumers to purchase their offerings by creating an effective marketing plan. Previous studies reported that corporate social responsibility (Elg and Hultman, 2016) and social media marketing (Duffett, 2015) play significant roles in influencing a consumer's purchase behaviour and attitude towards a brand. Other scholars also considered store atmosphere (Hosseini et al., 2014), perceived value and sales promotion (Andreti et al., 2013) as important predictors of consumer behaviour and brand choice.

However, although previous studies emphasized on both corporate social responsibility and social media marketing in influencing consumer behaviour, only few scholars examined their effects on purchase decision in retail industry settings, particularly in Malaysia. Furthermore, limited studies have explored the role of store environment and sales promotion in forming purchase decision. In other words, considerable research has already been done on examining consumers' purchase decisions in various business sectors, but there is no mutual agreement towards the factors conditioning consumers' purchase decision. Thus, this paper is designed to examine the effects of corporate social responsibility, social media marketing, store environment, perceived value and sales promotion on consumers' purchase decision with empirical data from department stores in Malaysia. The next sections present a brief review on past literature and methodological approach used in data collection; finally, the conclusion and recommendations for this study are established based on the findings.

\section{Literature review}

\section{Purchase decision}

Purchase decision involves a sequence of choices formed by a consumer before making a purchase which starts once he/she has a willingness to fulfil a need. The consumer should reach a decision with regard to the place of purchasing, the desired brand, model, purchase quantity, time to buy, amount of money to be spent and the method of payment. These decisions can be influenced by marketers by providing information about their products or services that may inform consumer's assessment process. Schiffman and Kanuk (2007) stated that consumers normally search for information relevant about a specified consumption-related need from their past experiences before looking for external sources of information. In other words, past purchase experience is regarded as an internal source of information that a consumer relies on before making a decision. In addition, several consumers' decisions are most likely to be formed by integrating past purchase experience as well as marketing programs and non-commercial information sources (Schiffman and Kanuk, 2007). Past literature also stressed that consumers usually attempt to minimize the risk in their purchase decisions (Chaipradermsak, 2007). 
Blackwell et al. (2001) reported that to comprehend consumers' purchasing decisions, marketing managers should understand their consumption process and the benefits of organizational products and services in their perceptions. The authors also added that when consumers intend to buy certain products, they pass through numerous phases which would influence their purchase decision process and post-purchase behaviour. The first phase represents the problem recognition wherein consumers intend to satisfy their needs and wants. The role of marketers in this phase emerges while using advertisements, personal selling and packaging to arouse the recognition of desired needs or wants. In the second phase, consumers begin to seek information from either internal sources (usually from their past experiences) about the products or outside sources, for example, friends, family, relatives, neighbours, annual reports, publications, sales persons, social media or packaging label. Finally, consumers evaluate the alternatives and select from brands that best suit them and satisfy their needs.

\section{Corporate social responsibility}

Corporate social responsibility has been conceptualized in the literature by a number of scholars. However, there is no consensus on its definition and measurement despite the significant amount of research on this topic. According to Kilcullen and Kooistra (1999, p. 158), corporate social responsibility can be conceptualized as "the degree of moral obligation that may be ascribed to corporations beyond their simple obedience to the laws of the state." Similarly, Kotler and Lee (2005) expressed the concept of corporate social responsibility as an organization's commitment to enhance the welfare of a society through voluntarily business activities and support from its resources. Erkollar and Oberer (2012) also illustrated that the majority of scholars view corporate social responsibility as a term through which organizations incorporate social and environmental aspects or considerations into their business processes and in their dealings with various stakeholders. Corporate social responsibility is usually used as a tactical tool for creating a positive brand image and attracting a larger number of customers (Reich et al., 2010).

In today's business environment that is characterized by strong rivalry, corporate social responsibility is regarded as an important strategy for assisting businesses to maintain their competitive strengths (Luo and Bhattacharya, 2006). Albus (2012) reported that corporate social responsibility represents an important strategic marketing tool than can be employed to develop a positive brand image. Corporate social responsibility is a key strategy that organizations should exploit, not only for the purposes of uplifting profit margins, but also due to the necessity to protect the environment. For example, organizations can be involved in social responsibility activities, such as treating business stakeholders (customers, vendors and staff) well. Pakseresht (2010) reported that several brands can be distinguished based on how they behave under the observation of business stakeholders. Consequently, the investment in corporate social responsibility programs enables a brand to foster its competitive advantage and improve its performance in the long term (El-Garaihy et al., 2014; Ghosh and Gurunathan, 2014).

In general, corporate social responsibility is one of the key strategies that business managers adopt to create an appealing personality for provoking consumer's identification with a brand (Hill and Langan, 2014). Prior studies provided ample evidence that the perceptions of consumers toward corporate social responsibility influence their responses to company's products or services (Torres et al., 2012), attitudes to products, identifications with a certain brand (Sen and Bhattacharya, 2001) and their behavioural intentions as well as actual purchase behaviour (Bagnoli and Watts, 2003). Past literature also showed that consumers' perception of corporate social responsibility has a positive and significant 
PRR

2,1

10

influence on their attitudes and purchase intention (Sen and Bhattacharya, 2001; Guchait et al., 2011). In addition, a number of studies reported that corporate social responsibility had a significant effect on consumers' purchase decisions (Bhattacharya and Sen, 2004; Elg and Hultman, 2016; Rodrigues and Borges, 2015). Based on the above discussion, the first hypothesis for this study is proposed as follows:

H1. Corporate social responsibility has a positive effect on purchase decision.

\section{Social media marketing}

Social media is an important marketing communication tool to reach and interact with customers at minimal cost and at different times of the day. Effective management and implementation of social media marketing is one of the key objectives and interests of several brands (Hanaysha, 2016). Successful brands have become aware of the power of social media marketing in today's interactive marketplace for building and maintaining customer relationships, as well as communicating and interacting with larger numbers of customers (Bulearca and Bulearca, 2010). Kaplan and Haenlein (2010) conceptualized social media as an internet-based program that provides a platform for consumers to express their own opinions, share information and past experiences using different social networks, blogs and other content areas. The efficiency of social media has empowered the marketers and customers with fast interaction and communication processes to enhance customer service, increase brand awareness and build strong customer-brand relationships. Using social media tools, consumers will have the chance to express their opinions to a larger number of individuals and also find the desired information quickly without incurring much cost (Severi et al., 2014).

Social media channels have appeared as the foremost convenient digital communication media through which several consumers can learn, share information and directly interact with business stakeholders (Chappuis et al., 2011; Qualman, 2013). With the existence of social media, business marketers will have the opportunity to interact with their existing and potential customers using two-way communications to obtain rich and valuable insights quickly and at lower costs. Marketers have also realized the additional values of social media channels through easier collaborations with brand referrals and quality of information sharing (Hudson et al., 2016). In addition, social media has enabled consumers to easily share important information about products or services offered by certain brands with their peers (Erdoğmuş and Cicek, 2012; Mangold and Faulds, 2009). Such exchanges have provided companies with several advantages represented by cost-effectiveness, increased brand awareness, improved brand recognition, higher customer loyalty and greater profit margins.

Effective implementation of marketing programs on social media can enable organizations to create beneficial relationships with their customers by increasing customer satisfaction (Hanaysha, 2016) and commitment as well as generating positive word of mouth. Through the continuous development and wide-ranging applications of several social media channels, many businesses considered this way of communication to be a noteworthy prospect. They have also started looking for the best ways of using social media for sustaining their businesses, creating healthier relationships with their consumers, marketing their products and services and developing reputable images for their brands to the public. To stay competitive in today's challenging business environments, it requires firms to put prime emphasis on social media as a marketing strategy. Global companies employ several experts and consultants in social media to gain better recommendations on the contents and features of their advertisements before sharing them on social media to 
maximize the efficiency of the marketing program (Erdoğmuş and Cicek, 2012).Moreover, customers regard social media communication as a tool to engage with various brands any time.

The recent developments in communication technologies have changed the ways in which consumers interact with each other. According to Brodie et al. (2013), through the support of social media, organizations can build their capabilities in engaging with committed and profitable customers, influencing their perceptions towards their products or services and sharing the information with others. The authors added that social media tools enable companies to learn more about their consumers' needs and expectations. Thus, marketing through social media channels is regarded as one the most cost-effective means of communication and useful approaches to obtain customers' information (Godes and Mayzlin, 2009). Soewandi (2015) also indicated that as a form of marketing communication, user-generated social media plays a significant role in forming brand choice. Further, prior literature revealed that a number of scholars (Khatib, 2016; Yogesh and Yesha, 2014) reported that social media marketing plays an important role in forming consumers' purchase decisions. Based on the above discussion, the following hypothesis is proposed:

H2. Social media marketing has a positive effect on purchase decision.

\section{Store environment}

The importance of constructing an appealing physical environment has attained considerable attention from several scholars and business managers due to its power in attracting and satisfying customers (Ali et al., 2013; Han and Ryu, 2009). In retail stores, the atmospheric environment is considered as a key competitive tactic employed by retailers to stimulate consumer behaviour and increase sales volumes (Chebat and Michon, 2003). The attributes of atmospheric environment focus on several stimuli such as colour, music, scene, layout and space, as they have been considered to be important clues for consumers (Oh et al., 2008). Lee and Jeong (2012) described physical environment as an environment that is shaped through overall layout, colour, design, decoration, surroundings and aesthetics. Particularly, the atmospheric environment in a store includes various stimuli such as ambience, colour, sound, scent, taste, layout and space, which are important clues for buyers. Prior research also established that physical environment enables a service provider to differentiate itself from rivals and influence customer's choice (Mahmood and Khan, 2014).

Assessing consumers' perceptions of the characteristics of a store's environment may form certain brand associations in their minds, enhance their perception of brand value and elevate buying intentions by minimizing cost and time, as well as the efforts in acquiring potential customers (Kumar et al., 2010). According to Mahmood and Khan (2014), the physical environment allows service providers to distinguish their brands from those of competitors and influence consumers' purchase decisions. Prior literature showed that store environment had a positive impact on consumer purchase behaviour. For instance, Belk (1975) found that the physical environment of a retail store influenced consumer's buying behaviour. Likewise, creating an attractive store atmosphere was stressed in the past studies as a key strategic factor that many retailers consider to stimulate consumer behaviour and improve their performance (Chebat and Michon, 2003). Further support can be found in the study by Richardson et al. (1996) who revealed that store atmosphere enhances the consumers' perceptions toward the service and product quality of the department store. Similarly, Newman and Patel (2004) indicated that store environment plays an important role in affecting consumer choice. 


\section{PRR}

2,1

Certain researchers who examined store environment in the retail context found that the ambience and store's design are important features that affect brand preference, service and product quality and price perceptions (Baker et al., 2002; Hanaysha, 2016; Thang and Tan, 2003). Consistent with the views of Newman and Patel (2004), physical environment is one of the key determinants of consumers' choices of a store. Richardson et al. (1996) suggested that the aesthetics of a store can improve the perceptions of customers toward the quality of its products. Further, Belk (1975) reported that the physical surroundings of a store represent the most important characteristics that influence consumer behaviour. A number of previous studies also confirmed that physical environment has a significant and positive impact on the purchase decision of consumers (Amofah et al., 2016; Hosseini et al., 2014; Hasan et al., 2016). Based on the above literature discussion, the third hypothesis for this study is proposed:

H3. Store environment has a positive effect on purchase decision.

\section{Sales promotion}

In the theoretical literature, promotion is regarded as a key element of marketing mix that aims to inform, encourage and remind the target market about a product of service offer in an attempt to influence the consumers' feelings, perceptions or purchasing decisions (Stanton et al., 2007). In other words, promotion programs are used by organizations with the purpose of communicating the benefits of certain products or services to a group of potential and existing customers (Reibstein, 1985). Sales promotion is widely accepted as an important component in marketing campaigns for inspiring and stimulating quicker and effective response (comprising purchase quantity and speed) to the sales of particular products or services. According to Kotler and Keller (2012), sales promotion represents a strong incentive tool for attracting consumers and increasing sales volumes. Agrawal (1996) conceptualized sales promotions as an aggressive strategy used by many brands to attract profitable customers and avoid issues of switching to other competitors. Thus, sales promotions are adopted by brands to motivate customers' purchases and reward fast responses (Kotler et al., 2004). Other benefits of sales promotion can be achieved by attracting the attention of consumers and influencing their purchase decisions.

In the previous studies, it can be observed that price promotion is one of the main strategies frequently used by a number of marketing managers to exploit their sales and performance (Zoellner and Schaefers, 2015). Essentially, promotional sales that can be grasped through several approaches such as customer coupons, displays and price reductions are usually used in diverse retail stores around the world. Price promotions as explained by Mullin and Cummins (2010) can comprise numerous forms such as buy one and then get the other one free, extra packs and money-off coupons. In the early 1990s, several retailers used price promotions to influence consumers who have price sensitivity by presenting to them the discounts on various product items. Generally, retail managers apply promotion strategies as incentives for obtaining a greater number of consumers and uplift their sales revenues (Cui et al., 2016). Currently, consumers deemed to be price sensitive tend to have high awareness towards the promotional deals and look for them frequently (Yeshin, 2006).

Many organizations focus on sales promotions to develop and penetrate new markets, form positive brand image, convey information, improve and elevate sales and add value to the products or services as well as differentiate themselves from competitors. In past literature, several scholars analysed the association between customer loyalty and sales promotion and highlighted that current customers respond positively when they experience sales promotions (Ehrenberg and Sharp, 2000). Additionally, sales promotions influence and 
stimulate customers' purchase decisions by conveying them that the products or services of a certain brand are better than those of competitors (Hanaysha, 2016). Köksal (2014) added that sales promotions have significant positive effects on brand preference and consumers' purchase intention. This is in line with Blythe (2005) who illustrated that sales promotion plays a significant role in building brand awareness that can later result in purchase decision. Furthermore, previous studies reported that promotional offers have a significant influence on consumer's purchase decision (Andreti et al., 2013; Biswas et al., 2013). Based on the above literature, the fourth hypothesis for this study is presented as follows:

Malaysian retail market

H4. Sales promotion has a positive effect on purchase decision.

\section{Perceived value}

Value exists when the benefits of purchasing a product or services are perceived to be better than what is spent. Zeithaml (1988) illustrated that customers' perceived value can be determined through various elements such as want satisfaction, acceptable product or service for the paid price, low price in comparison with competitors and what customers get for what they give in exchange. Perceived value refers to the general assessment of consumers about the benefit of a product or service in relation with what is given and what is received in return. In marketing literature, perceived value was also defined as the psychological evaluations and feelings of consumers about the perceived benefits of purchasing a product or service (Ali et al. 2013). According to Dube and Renaghan (2000) and Mehmood and Hanaysha (2016), it is important to provide added values to build customers' loyalty and satisfaction. Furthermore, certain researchers proposed that the benefits of customer satisfaction and product quality provide superior implications for both an organization and its customers (Birgelen et al., 1997). A number of studies also showed that perceived value plays an important role in affecting consumer's purchase decision (Cheng et al., 2006; de Medeiros et al., 2016; Yee and San, 2011). Based on the discussion that is presented above, the following hypothesis is presented:

\section{H5. Perceived value has a positive effect on purchase decision.}

Based on the above literature review and existing research gaps between the selected variables, the framework for this research is presented as follows (Figure 1).

\section{Methodology}

This research aimed to examine the predictors of a purchase decision in the retail industry. Therefore, the data was collected using a survey method from 278 customers of several department stores in East Coast Malaysia. The selection of a quantitative approach to

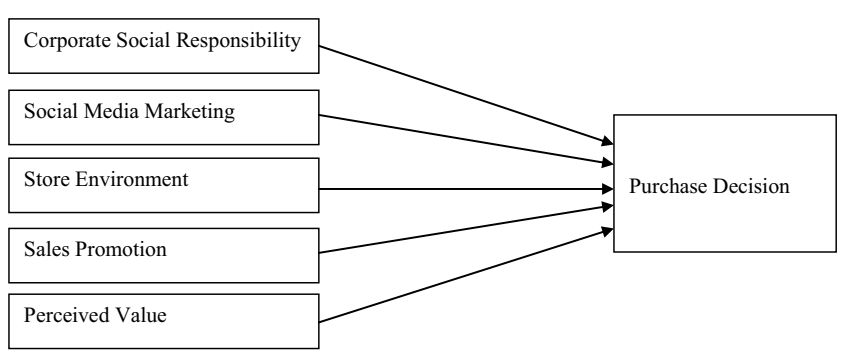

Figure 1. Research framework 
PRR

2,1

conduct this research was considered appropriate to involve as many participants as possible and obtain larger number of responses. Additionally, a quantitative survey methodology is the researchers' best choice when the targeted population comprises a larger number of individuals without requiring special skills to fill in the questionnaire. McDaniel and Gates (1998) illustrated that the quantitative survey enables researchers to conduct statistical analysis and generalize the results in a given context. To minimize the response bias and sampling error, the respondents were briefed about the purpose of the study and assured that their answers will be kept confidential.

Before starting the data collection process, the questionnaire was designed based on several measurement items for the constructs. Purchase decision was measured using a fiveitem scale adapted from the study of Shareef et al. (2008). Furthermore, the measurement scale of corporate social responsibility was adapted from Tong and Wong (2014). To measure social media marketing, five items were taken from the study by Schivinski and Dabrowski (2014). In addition, the items used to measure store environment were taken from the study by Hussain and Ali (2015). To measure sales promotion, a total of four items were taken from Villarejo-Ramos and Sánchez-Franco (2005) and modified to fit the context of this study. Finally, perceived value was measured using four items taken from PunchevaMichelotti and Michelotti (2010). All of the items were measured on a five-point Likert scale which ranges from strongly disagree to strongly agree.

\section{Analysis of results}

Out of the 384 sets of questionnaires distributed to visitors of department stores in East Coast Malaysia, only 278 responses were received from the participants. While analysing the demographic characteristics, it was found that 54.7 per cent of the respondents were women and men represented 45.3 per cent. The respondents' profile also showed that most of the participants held a bachelor degree certificate. Additionally, the respondents were classified based on monthly income and it was found that 48 participants (17.2 per cent) received an average income of less than RM 500 per month, while 15 participants (5.4 per cent) obtained a monthly income between RM 501 and RM 1000. A total of 44 responses (52 per cent) were represented by the participants with an average income of RM 1,001 to RM 4,000. Those whose monthly income ranged from RM 4001 and above accounted for 71 (25.4 per cent) responses. Furthermore, the reliability assumptions were established on all constructs and the results revealed that the value of Cronbach's alpha for the measurement scales of constructs exceeded the cut-off point of 0.70 . Therefore, the reliability assumptions are fulfilled (Appendix).

For testing the hypotheses of this study, structural equation modelling method was used and the procedure was carried out using AMOS 18. At first, the measurement model comprising all measurement items of the constructs was drawn to calculate confirmatory factor analysis. The results indicated that the factor loadings for remaining items of each construct exceeded 0.50; therefore, convergent validity was achieved. Then, the structural model with the residual items was estimated. According to Hair et al. (2010), the hypotheses can be tested when the fit indices in the structural model fall in the accepted range. Overall, the findings as shown in Figure 2 indicate that the structural model for this study maintained a reasonable fit with the data with the chi-square value being $376.3331(p=0.000)$; values of other criteria $(\mathrm{GFI}=0.841, \mathrm{AGFI}=0.792, \mathrm{df}=230, \mathrm{TLI}=0.909, \mathrm{CFI}=0.924$ and $\mathrm{RMSEA}=$ 0.063) attained the acceptable cut-off point based on the suggestions of Hair et al. (2010).

To check the normal distribution of the data set, multicollinearity was calculated using AMOS 18 for all variables. According to Tabachnick and Fidell (2001), multicollinearity issues exist when the relationship between any two distinct variables is 0.90 or more. As shown in Table I, the relationship between any two different variables is less than 0.90 ; thus, there is no 


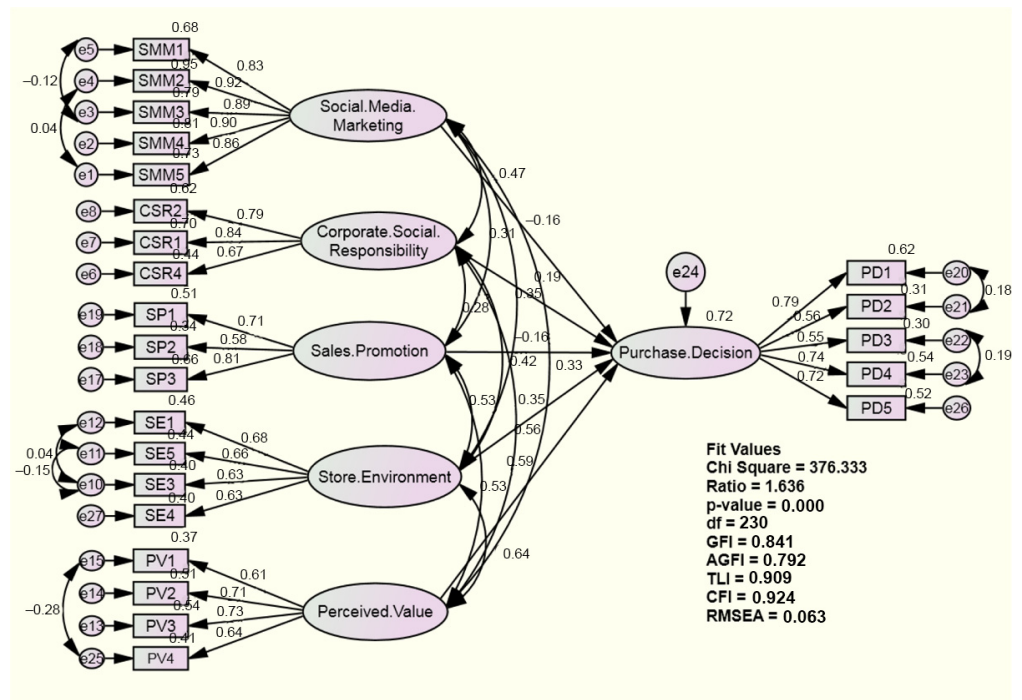

sign of multicollinearity issues in the current data set. Furthermore, the discriminant validity among the constructs was verified by computing the average variance extracted (AVE) and correlation values between each pair of constructs. As cited by de Pablos (2016), Bagozzi et al. (1991) reported that discriminant validity is achieved when the correlation values between pairs of constructs are less than 1.00. This was further advocated by Mohammad and Yusoff (2017) who stated that discriminant validity exists when the correlation values between pairs constructs are below 0.95 . Overall, the output confirmed the existence of discriminant validity among the constructs.

After achieving an acceptable fit for the structural model and fulfilling the reliability and validity assumptions, the hypotheses in this study were verified. The results presented in Table II show that corporate social responsibility has a significant positive effect on purchase decision $(\beta=0.188, \mathrm{C} . \mathrm{R} .=1.803, p<0.10)$; hence, $H 1$ is accepted. Contrary to expectations, the results showed that social media marketing has an insignificant effect on purchase decision $(\beta=-0.165, \mathrm{C} . \mathrm{R} .=-1.536, p>0.05)$; therefore, $H 2$ is rejected. Moreover, the analysis confirmed that store environment has a significant positive effect on purchase decision $(\beta=0.351$, C.R. $=2.637, p<0.05)$; consequently, $H 3$ is accepted. The results also indicated that sales promotion $(\beta=-0.158$, C.R. $=-2.035, p<0.05)$ has a significant

\begin{tabular}{|c|c|c|c|c|c|c|c|}
\hline & $\begin{array}{c}\text { Sales } \\
\text { promotion }\end{array}$ & $\begin{array}{l}\text { Perceived } \\
\text { value }\end{array}$ & $\begin{array}{c}\text { Store } \\
\text { environment }\end{array}$ & CSR & SMM & $\begin{array}{l}\text { Purchase } \\
\text { decision }\end{array}$ & \\
\hline Sales promotion & 1 & & & & & & \\
\hline Perceived value & 0.526 & 1 & & & & & \\
\hline Store environment & 0.531 & 0.643 & 1 & & & & \\
\hline CSR & 0.277 & 0.561 & 0.421 & 1 & & & \\
\hline Social media marketing & 0.314 & 0.326 & 0.352 & 0.469 & 1 & & Table I. \\
\hline Purchase decision & 0.395 & 0.734 & 0.582 & 0.556 & 0.235 & 1 & Discriminant validity \\
\hline
\end{tabular}


PRR

2,1

negative effect on purchase decision; thus, $H 4$ is rejected. Finally, the findings of this paper showed that perceived value has a significant positive effect on purchase decision $(\beta=$ 0.593, C.R. $=4.142, p<0.05)$, which implied that that $H 5$ is validated. Overall, these factors explain 72 per cent of the total variance in purchase decision.

\section{Discussion and conclusion}

16 This study aimed to examine the effects of corporate social responsibility, social media marketing, sales promotion, store environment and perceived value on purchase decision in the retail industry. The findings revealed that corporate social responsibility has a significant positive effect on purchase decision and this is in line with previous researches (Elg and Hultman, 2016; Green and Peloza, 2011). Hassan et al. (2013) stated that if individuals feel that a brand has social responsibility towards them and the society, they will prefer to select its products/services. Similarly, Handelman and Arnold (1999) found that marketing activities which are socially responsible influence consumers' evaluation of a brand and enhance their willingness to purchase its offerings. The second purpose of this paper was to test the link between social media marketing and purchase decision. Contrary to expectations, the results showed that the effect of social media marketing on a consumer's purchase decision is insignificant. The insignificant result could be attributed to the lack of or inefficient marketing activities among the selected retail stores through social media. Additionally, negative word of mouth through social media sites could lead to negative perceptions among consumers, which may hinder their purchase intentions. Overall, social media sites can be a strong platform for building brand awareness, but its effect on purchase decision may not be strong enough in the retail context.

The findings of this study also showed that the store environment has a significant positive impact on purchase decision. The result was supported by many scholars (Amofah et al., 2016; Hasan et al., 2016) who confirmed that the store environment plays an important role in affecting consumer purchase behaviour. Mahmood and Khan (2014) indicated that the store environment enables a brand to distinguish itself from competitors, thus leading to favourable customer's choice. Therefore, store environment is an important means through which retailers can influence consumers' behaviour and their purchase decisions. Furthermore, the results revealed that sales promotion has a negative effect on purchase decision. Eleboda (2017) also confirmed that sales promotion had a negative impact on consumer purchase decision. The result was supported by Santini et al. (2015) who stated that much discount leads to a state of discomfort among consumer, which will ultimately causes a sense of caution highlighted earlier, associating negatively with the hedonic features. Furthermore, Simonson et al. (1994) confirmed that sales promotion had a negative impact on brands. Similar views were shared by Shrestha (2015) who revealed that sales promotion does not have any effect on brand building and may lead to declining impacts for the brand, especially those which are well established. Thus, this study concludes that sales

Table II.

Results of hypotheses

\begin{tabular}{lrrrc}
\hline Hypotheses & Standard $\beta$ & SE & $t$-value & $p$ \\
\hline H1. CSR $\rightarrow$ Purchase decision & 0.188 & 0.089 & 1.803 & 0.071 \\
H2. Social media marketing $\rightarrow$ Purchase decision & -0.165 & 0.078 & -1.536 & 0.125 \\
H3. Store environment $\rightarrow$ Purchase decision & 0.351 & 0.134 & 2.637 & 0.008 \\
H4. Sales promotion $\rightarrow$ Purchase decision & -0.158 & 0.045 & -2.035 & 0.042 \\
H5. Perceived value $\rightarrow$ Purchase decision & 0.593 & 0.132 & 4.142 & $* * *$ \\
\hline
\end{tabular}


promotions could have a negative effect on consumers' perceptions towards brand quality as lower priced items tend to have low quality.

Finally, the outcomes of this research confirmed that perceived value has a significant positive effect on purchase decision. The results were supported by a number of researchers (Astuti, Silalahi, and Wijaya, 2015; Bakırtaş, 2013; Cheng et al., 2006; Nochai and Nochai, 2011) who reported that perceived value plays a significant role in affecting purchase decision. Demirgünescedil (2015) also reported that perceived value plays an important role in affecting consumers' purchase decisions. This means that marketing programs associated with added values reinforce consumers' purchases and improve organizational profitability. Consequently, retailers are recommended to cultivate their customer value to attain greater competitive advantages in the presence of competitive marketplace environment. This study also suggests that retailers should focus on communicating their product values to customers and compare their prices with those competitors and observe how they influence consumers' purchase decisions.

This study has some limitations which would provide directions for future research. Firstly, the main focus of the study was restricted to department stores and involved only consumers. Therefore, future studies can extend the scope by collecting the data at different areas in the country and include several staff of department stores to get better insights into the important factors in retail sector. Secondly, the data were gathered through quantitative survey using structured questions; thus, future studies can involve other research methodologies to confirm the findings. Additionally, the sample size used in this study may not be enough to represent the population. Thus, future studies are recommended to rely on larger sample sizes and in different industry contexts. Future studies may also examine other marketing factors, such as cultural factors and reference groups to gain further insights about their role in affecting consumers' purchase decision in the retail sector. Finally, only five independent variables were examined in this study; hence, future research can consider other factors that can influence consumers' purchase decision in the Malaysian retail sector such as service quality and store image.

\section{Implications}

The examination of the direct effects of corporate social responsibility, social media marketing, store environment, sales promotion and perceived value on purchase decision in the retail industry provides a theoretical contribution to the existing literature in this field. This study is one of the few research studies which attempted to examine the causal link between these variables. Particularly, the findings have theoretical significance by providing empirical evidence with regard to the relationships between the stated factors and purchase decision. Furthermore, there are useful practical implications for the business practitioners of retail stores. Managers can benefit from the results of this research to achieve better recognition and sustainable competitive advantage. The findings of this study also indicate that managers should understand the implications with respect to social media marketing in the Malaysian context; although this variable was found to be insignificant in affecting purchase decision in the retail context, it may yield different outcomes in future research.

\section{References}

Agrawal, D. (1996), "Effect of brand loyalty on advertising and trade promotions: a game theoretic analysis with empirical evidence", Marketing Science, Vol. 15 No. 1, pp. 86-108.

Albus, H. (2012), "The effects of corporate social responsibility on service recovery evaluations in casual dining restaurants", Master's dissertation, University of Central Florida Orlando, FL. 
PRR

2,1

Ali, F., Omar, R. and Amin, M. (2013), "An examination of the relationships between physical environment, perceived value, image and behavioural intentions: a SEM approach towards Malaysian resort hotels", Journal of Hotel and Tourism Management, Vol. 27 No. 2, pp. 9-26.

Amofah, O., Gyamfi, I. and Tutu, C.O. (2016), "The influence of service marketing mix on customer choice of repeat purchase of restaurant in Kumasi, Ghana", European Journal of Business and Management, Vol. 8 No. 11, pp. 102-112.

Andreti, J., Zhafira, N.H., Akmal, S.S. and Kumar, S. (2013), "The analysis of product, price, place, promotion and service quality on customers' buying decision of convenience store: a survey of young adult in Bekasi, West Java, Indonesia”, International Journal of Advances in Management and Economics, Vol. 2 No. 6, pp. $72-78$.

Astuti, R., Silalahi, R.L.R. and Wijaya, G.D.P. (2015), "Marketing strategy based on marketing mix influence on purchasing decisions of Malang apples consumers at giant Olympic garden mall (MOG), Malang city, East Java province, Indonesia”, Agriculture and Agricultural Science Procedia, Vol. 3, pp. 67-71.

Bagnoli, M. and Watts, S.G. (2003), "Selling to socially responsible consumers: competition and the private provision of public goods", Journal of Economics \& Management Strategy, Vol. 12 No. 3, pp. 419-445.

Bagozzi, R.P., Yi, Y. and Phillips, L.W. (1991), “Assessing construct validity in organizational research”, Administrative Science Quarterly, Vol. 63, pp. 421-458.

Baker, J., Parasuraman, A., Grewal, D. and Voss, G.B. (2002), "The influence of multiple store environment cues on perceived merchandise value and patronage intentions", Journal of Marketing, Vol. 66 No. 2, pp. 120-141.

Bakırtaş, H. (2013), "Impact of sales promotion on purchase decision of consumers: an application in tourism sector", Journal of Human Sciences, Vol. 10 No. 1, pp. 676-694.

Basil, G., Etuk, E. and Ebitu, E.T. (2013), “The marketing mix element as determinants of consumer's choice of made-in-Nigeria shoes in Cross River state", European Journal of Business and Management, Vol. 5 No. 6, pp. 141-147.

Belk, R.W. (1975), "Situational variables and consumer behaviour", Journal of Consumer Research, Vol. 2 No. 3, pp. 157-164.

Bhattacharya, C.B. and Sen, S. (2004), "Doing better at doing good: when, why, and how consumers respond to corporate social initiatives", California Management Review, Vol. 47 No. 1, pp. 9-24.

Biswas, A., Bhowmick, S., Guha, A. and Grewal, D. (2013), "Consumer evaluations of sale prices: role of the subtraction principle”, Journal of Marketing, Vol. 77, No. 4, pp. 49-66.

Blackwell, R.D., Miniard, P.W. and Engel, J.F. (2001), Consumer Behavior, 9th ed., South-Western Thomas Learning, Mason, $\mathrm{OH}$.

Blythe, S.E. (2005), "Digital signature law of the United Nations, European Union, United Kingdom and United States: promotion of growth in E-commerce with enhanced security", Richmond Journal of Law and Technology, Vol. 11 No. 2, pp. 6-8.

Birgelen, M., Wetzels, M. and de Ruyter, K. (1997), “Commitment in service relationships: An empirical test of its antecedents and consequence", paper presented at the EMAC Annual Conference, University of Warwick, 20-23 May, pp. 1255-1271.

Brodie, R.J., Ilic, A., Juric, B. and Hollebeek, L. (2013), "Consumer engagement in a virtual Brand community: an exploratory analysis", Journal of Business Research, Vol. 66 No. 1, pp. 105-114.

Bulearca, M. and Bulearca, S. (2010), "Twitter: A viable marketing tool for SMEs", Journal of Global Business \& Management Research, Vol. 2 No. 4, pp. 296-309.

Chaipradermsak, T. (2007), "The influential factors on consumers' purchasing decision in Bangkok pet retailing business", MBA Thesis, Shinawatra University. 
Chappuis, B. Gaffey, B. and Parvizi, P. (2011), "Are your customers becoming digital junkies", McKinsey Quarterly, available at: www.mckinsey.com/business-functions/marketing-and-sales/ our-insights/are-your-customers-becoming-digital-junkies (accessed 8 July 2017).

Chebat, J.C. and Michon, R. (2003), "Impact of ambient odors on mall shoppers' emotions, cognition, and spending: a test of competitive causal theories", Journal of Business Research, Vol. 56 No. 7 , pp. 529-539.

Cheng, M.S., Cripps, H. and Chen, C.H. (2006), "The relationships between perceived quality, perceived value, and purchase intentions - a study in internet marketing”, Australian and New Zealand Marketing Academy Conference, Brisbane, pp. 1-7, available at: http:/eprints.utar.edu.my/1921/ 1/Microsoft_Word_-_Factors_influencing_consumer's_willingness_to_purchase_PLBs.pdf

Cui, B., Yang, K. and Chou, T. (2016), "Analyzing the impact of price promotion strategies on manufacturer sales performance", Journal of Service Science and Management, Vol. 9 No. 2, pp. 182-187.

de Medeiros, J.F., Ribeiro, J.L.D. and Cortimiglia, M.N. (2016), "Influence of perceived value on purchasing decisions of green products in Brazil", Journal of Cleaner Production, Vol. 110, pp. 158-169.

de Pablos, P.O. (2016), "Managerial strategies and solutions for business success in Asia", Business Science Reference, University of Oviedo.

Demirgünescedil, B.K. (2015), "Relative importance of perceived value, satisfaction and perceived risk on willingness to pay more", International Review of Management and Marketing, Vol. 5 No. 4, pp. 211-220.

Dube, L. and Renaghan, L. (2000), “Creating visible customer value”, Cornell Hotel and Restaurant Administration Quarterly, Vol. 41 No. 1, pp. 62-72.

Duffett, R.G. (2015), "Facebook advertising's influence on intention-to-purchase and purchase amongst millennials", Internet Research, Vol. 25 No. 4, pp. 498-526.

Eleboda, S.S. (2017), "Sales promotion as a strategy in service marketing: exploring the believability dilemma and consumer purchase decision", American Journal of Marketing Research, Vol. 3 No. 2, pp. 8-15.

Elg, U. and Hultman, J. (2016), "CSR: retailer activities vs consumer buying decisions”, International Journal of Retail \& Distribution Management, Vol. 44 No. 6, pp. 640-657.

El-Garaihy, W.H., Mobarak, A.K.M. and Albahussain, S.A. (2014), "Measuring the impact of corporate social responsibility practices on competitive advantage: a mediation role of reputation and customer satisfaction", International Journal of Business and Management, Vol. 9 No. 5, pp. 109-124.

Ehrenberg, A. and Sharp, B. (2000), "Managerial uses of descriptive marketing models-the case of the Dirichlet", Doctoral dissertation, Griffith University.

Erdoğmuş, ĐE. and Cicek, M. (2012), "The impact of social media marketing on Brand loyalty", Procedia-Social and Behavioral Sciences, Vol. 58, pp. 1353-1360.

Erkollar, A. and Oberer, B.J. (2012), "Responsible business: the European Union is driving forward the European strategies on corporate social responsibility", Journal of EU Research in Business, Vol. 2012, pp. 1-15.

Ghosh, D. and Gurunathan, L. (2014), "Linking perceived corporate social responsibility and intention to quit: the mediating role of job embeddedness", Vision: The Journal of Business Perspective, Vol. 18 No. 3, pp. 175-183.

Godes, D. and Mayzlin, D. (2009), "Firm-created word-of-mouth communication: Evidence from a field test”, Marketing Science, Vol. 28 No. 4, pp. 721-739.

Green, T. and Peloza, J. (2011), "How does corporate social responsibility create value for consumers?", Journal of Consumer Marketing, Vol. 28 No. 1, pp. 48-56.

Guchait, P. Anner, M. and Wu, L. (2011), "Customer perceptions of corporate social responsibility of service firms: Impact on customer attitudes and behavioral intentions", available at: http://scholarworks. umass.edu/cgi/viewcontent.cgi?article=1034\&context=gradconf_hospitality (accessed 5 January 2016). 
PRR

2,1

Hair, J.F., Jr, Black, W.C., Jr, Babin, B.J., Anderson, R.E. and Tatham, R.L. (2010), Multivariate Data Analysis, 7th ed., Prentice Hall, Upper Saddle River, NJ.

Han, H. and Ryu, K. (2009), "The roles of the physical environment, price perception, and customer satisfaction in determining customer loyalty in the family restaurant industry", Journal of Hospitality and Tourism Research, Vol. 33 No. 4, pp. 487-510.

Hanaysha, J. (2016), "The importance of social media advertisements in enhancing Brand equity: a study on fast food restaurant industry in Malaysia", Business and Economic Research, Vol. 6 No. 1, pp. 46-51.

Handelman, J.M. and Arnold, S.J. (1999), "The role of marketing actions with a social dimension: appeals to the institutional environment", Journal of Marketing, Vol. 63 No. 3, pp. 33-48.

Hasan, S., Wahid, M., Syafi, M. and Basalamah, I. (2016), "Marketing mix effect on the decision of customers in the matter in choosing the home purchase loans in pt.Bni 46 griya bni (persero) tbk branch Makassar", International Journal of Business and Management Invention, Vol. 5 No. 6, pp. 20-30.

Hassan, L., Shaw, D., Shiu, E., Walsh, G. and Parry, S. (2013), "Uncertainty in ethical consumer choice: A conceptual model”, Journal of Consumer Behaviour, Vol. 12 No. 3, pp. 182-193.

Hill, R.P. and Langan, R. (2014), Handbook of Research on Marketing and Corporate Social Responsibility, Edward Elgar Publishing, Northampton, MA.

Hosseini, Z., Jayashree, S. and Malarvizhi, C. (2014), "Store image and its effect on customer perception of retail stores", Asian Social Science, Vol. 10 No. 21, pp. 223-235.

Hudson, S., Huang, L., Roth, M.S. and Madden, T.J. (2016), "The influence of social media interactions on consumer-brand relationships: a three-country study of brand perceptions and marketing behaviors", International Journal of Research in Marketing, Vol. 33 No. 1, pp. 27-41.

Hussain, R. and Ali, M. (2015), "Effect of store atmosphere on consumer purchase intention", International Journal of Marketing Studies, Vol. 7 No. 2, pp. 35-43.

Kaplan, A.M. and Haenlein, M. (2010), "Users of the world, unite! the challenges and opportunities of social media”, Business Horizons, Vol. 53 No. 1, pp. 59-68.

Khatib, F. (2016), "The impact of social media characteristics on purchase decision empirical study of Saudi customers in Aseer region”, International Journal of Business and Social Science, Vol. 7 No. 4, pp. 41-50.

Kilcullen, M. and Kooistra, J.O. (1999), "At least do no harm: sources on the changing role of business ethics and corporate social responsibility”, Reference Services Review, Vol. 27 No. 2, pp. 158-178.

Köksal, Y. (2014), “The efficiency of monetary and non-monetary sales promotions on brand preference: a case of Albanian GSM companies", Journal of the School of Business Administration, Istanbul University, Vol. 43 No. 2, pp. 319-331.

Kotler, P. and Keller, K.L. (2012), Marketing Management, 14th ed., Pearson Education Limited, Upper Saddle River, NJ.

Kotler, P. and Lee, N. (2005), Corporate Social Responsibility: Doing the Most Good for Your Company and Your Cause, John Wiley \& Sons, Hoboken, NJ.

Kotler, P., Wong, V., Saunders, J. and Armstrong, G. (2004), Principles of Marketing, 4th ed., PrenticeHall, NJ.

Kumar, I., Garg, R. and Rahman, Z. (2010), "Influence of retail atmospherics on customer value in an emerging market condition", Great Lakes Herald, Vol. 4 No. 1, pp. 1-13.

Lee, S. and Jeong, M. (2012), "Effects of e-servicescape on consumers' flow experiences", Journal of Hospitality and Tourism Technology, Vol. 3 No. 1, pp. 47-59.

Luo, X. and Bhattacharya, C.B. (2006), "Corporate social responsibility, customer satisfaction, and market value", Journal of Marketing, Vol. 70 No. 4, pp. 1-18.

McDaniel, C. and Gates, R.H. (1998), Marketing Research Essentials, South-Western College, $\mathrm{OH}$. 
Mahmood, R. and Khan, S.M. (2014), "Impact of service marketing mixes on customer perception: a study on Eastern Bank Limited, Bangladesh", European Journal of Business and Management, Vol. 6 No. 34, pp. 164-167.

Mangold, W.G. and Faulds, D.J. (2009), "Social media: the new hybrid element of the promotion mix", Business Horizons, Vol. 52 No. 4, pp. 357-365.

Mohammad, J.A.M. and Yusoff, M.S.B. (2017), "Psychometric properties of the mentor behaviour scale in a sample of Malaysian medical students", Journal of Taibah University Medical Sciences, Vol. 10 No. 2, pp. 159-168.

Mullin, R. and Cummins, J. (2010), Sales Promotion: How to Create, Implement and Integrate Campaigns That Really Work, 4th ed., Kogan Page Publishers.

Newman, A.J. and Patel, D. (2004), "The marketing directions of two fashion retailers", European Journal of Marketing, Vol. 38 No. 7, pp. 770-789.

Nochai, R. and Nochai, T. (2011), "The influence of sale promotion factors on purchase decisions: a case study of portable PCs in Thailand", International Proceedings of Economics Development \& Research, p. 130.

Oh, J., Fiorito, S.S., Cho, H. and Hofacker, C.F. (2008), "Effects of design factors on store image and expectation of merchandise quality in web-based stores", Journal of Retailing and Consumer Services, Vol. 15 No. 4, pp. 237-249.

Pakseresht, A. (2010), "Brand equity and corporate responsibility: a review of brand valuation methods", available at: http://stud.epsilon.slu.se/1932/1/pakseresht_a_101019.pdf (accessed 20 January 2016).

Puncheva-Michelotti, P. and Michelotti, M. (2010), "The role of the stakeholder perspective in measuring corporate reputation”, Marketing Intelligence \& Planning, Vol. 28 No. 3, pp. 249-274.

Qualman, E. (2013), Socialnomics: How Social Media Transforms the Way We Live and Do Business, John Wiley \& Sons, Hoboken, NJ.

Reibstein, D.J. (1985), Marketing, Concepts, Strategies, and Decisions, Prentice Hall, NJ.

Reich, A.Z., Xu, Y.H. and McCleary, K.W. (2010), "The influence of social responsibility image relative to product and service quality on brand loyalty: an exploratory study of quick-service restaurants", Hospitality Review, Vol. 28 No. 1, pp. 20-50.

Richardson, P., Jain, A.K. and Dick, A. (1996), "The influence of store aesthetics on evaluation of private label brands", Journal of Product \& Brand Management, Vol. 5 No. 1, pp. 19-28.

Rodrigues, P. and Borges, A.P. (2015), "Corporate social responsibility and its impact in consumer decision-making”, Social Responsibility Journal, Vol. 11 No. 4, pp. 690-701.

Santini, F.D.O., Sampaio, C.H., Perin, M.G. and Vieira, V.A. (2015), "An analysis of the influence of discount sales promotion in consumer buying intent and the moderating effects of attractiveness", Revista de Administração (São Paulo), Vol. 50 No. 4, pp. 416-431.

Schiffman, L.G. and Kanuk, L.L. (2007), Consumer Behavior, 9th ed., Prentice-Hall, NJ.

Schivinski, B. and Dabrowski, D. (2014), "The effect of social media communication on consumer perceptions of brands", Journal of Marketing Communications, Vol. 22 No. 2, pp. 1-26.

Sen, S. and Bhattacharya, C.B. (2001), "Does doing good always lead to doing better? Consumer reactions to corporate social responsibility", Journal of Marketing Research, Vol. 38 No. 2, pp. 225-243.

Severi, E., Ling, K.C. and Nasermoadeli, A. (2014), "The impacts of electronic word of mouth on brand equity in the context of social media", International Journal of Business and Management, Vol. 9 No. 8, pp. 84-96.

Shamsher, R. (2015), "Store image and its impact on consumer behaviour", Elk Asia Pacific Journal of Marketing and Retail Management, Vol. 7 No. 2, pp. 1-27. 
PRR

2,1

Shareef, M.A., Kumar, U. and Kumar, V. (2008), "Role of different electronic-commerce (EC) quality factors on purchase decision: a developing country perspective", International Journal of Electronic Marketing and Retailing, Vol. 2 No. 2, pp. 92-113.

Shrestha, A. (2015), "Effects of sales promotion on purchasing decision of customer: a case study of Baskin Robbins ice-cream franchise Thailand", Master's thesis, Bangkok University.

Simonson, I., Carmon, Z. and O'curry, S. (1994), "Experimental evidence on the negative effect of product features and sales promotions on brand choice", Marketing Science, Vol. 13 No. 1, pp. $23-40$.

Soewandi, M. (2015), "The impact of social media communication forms on Brand equity dimensions and consumer purchase intention", iBuss Management, Vol. 3 No. 2, pp. 204-213.

Stanton, W.J., Etzel, M.J. and Walker, B.J. (2007), Marketing, 14th ed., McGraw-Hill, Irwin.

Tabachnick, B.G. and Fidell, L.S. (2001), Using Multivariate Statistics, Allyn and Bacon, Boston, MA.

Thang, D.C.L. and Tan, B.L.B. (2003), "Linking consumer perception to preference of retail stores: an empirical assessment of the multi-attributes of store image", Journal of Retailing and Consumer Services, Vol. 10 No. 4, pp. 193-200.

Tong, C. and Wong, A. (2014), "The influences of corporate social responsibility to customer repurchases intentions, customer word-of-mouth intentions and customer perceived food quality of fast-food restaurants in Hong Kong and the mediating effects of corporate reputation", British Journal of Economics, Management \& Trade, Vol. 4 No. 11, pp. 1655-1678.

Torres, A., Bijmolt, T.H., Tribó, J.A. and Verhoef, P. (2012), "Generating global Brand equity through corporate social responsibility to key stakeholders", International Journal of Research in Marketing, Vol. 29 No. 1, pp. 13-24.

Villarejo-Ramos, A.F. and Sánchez-Franco, M.J. (2005), "The impact of marketing communication and price promotion on brand equity", Journal of Brand Management, Vol. 12 No. 6, pp. 431-444.

Yee, C.J. and San, N.C. (2011), "Consumers' perceived quality, perceived value and perceived risk towards purchase decision on automobile", American Journal of Economics and Business Administration, Vol. 3 No. 1, pp. 47-57.

Yeshin, T. (2006), Sales Promotion, Cengage Learning EMEA.

Yogesh, F. and Yesha, M. (2014), "Effect of social media on purchase decision", Pacific Business Review International, Vol. 6 No. 11, pp. 45-50.

Zeithaml, V.A. (1988), "Consumer perceptions of price, quality, and value: a means-end model and synthesis of evidence", The Journal of Marketing, Vol. 52 No. 3, pp. 2-22.

Zoellner, F. and Schaefers, T. (2015), "The impact of price promotion types on sales and brand perception of premium products", Developments in Marketing Science: Proceedings of the Academy of Marketing Science in Ideas in Marketing: Finding the New and Polishing the Old, Springer, Cham, pp. 528-528. 
Social media marketing $(\alpha=0.942)$

SMM1 The social media marketing for this store's brand are frequently seen

SMM2 The social media advertisements for this store's brand are very attractive

SMM3 The social media advertisements for this store brand perform well in comparison to

those of other stores

SMM4 This store's brand offers extensive advertisements on social media

SMM5 The social media advertisements for the brand of this store can be easily remembered

Corporate social responsibility $(\alpha=0.810)$

CSR1 This store is committed to improving the welfare of the communities in which it operates

CSR2 This store's brand is very concerned with environmental protection

CSR4 This store's brand is very concerned with customers' benefits

Sales promotion ( $\alpha=0.793$ )

SP1 Price deals for this store are frequently offered $\quad 0.712$

SP2 Seasonal promotions in this store are available $\quad 0.580$

$\begin{array}{ll}\text { SP3 Price deals for this store are attractive } & 0.811\end{array}$

Store environment $(\alpha=0.770)$

SE1 This store is always clean $\quad 0.677$

SE5 This store has a pleasant environment created by music $\quad 0.661$

SE3 The atmosphere and decorations in the store encourages me to revisit it again $\quad 0.635$

SE4 The quality of the air conditioning in the store makes my presence in it comfortable 0.633

Perceived value $(\alpha=0.736)$

PV1 This store offers products and services that are good value for money $\quad 0.610$

$\begin{array}{ll}\text { PV2 This store provides excellent value to its customers } & 0.714\end{array}$

PV3 The products and services of this store are very reliable $\quad 0.732$

$\begin{array}{lll}\text { PV4 The staffs in this store provide technical support to customers } & 0.643\end{array}$

Purchase decision $(\alpha=0.769)$

PD1 I feel good about my decision to purchase products from this store's brand 0.788

PD2 I will positively recommend this store's brand to other people 0.557

PD3 I frequently purchase from this store's brand 0.546

PD4 I intent to purchase again from this store's brand in the future $\quad 0.736$

PD5 Overall, I am satisfied about my purchase of goods from this store $\quad 0.720$

Table AI.

Measurements of constructs

\begin{abstract}
About the author
Jalal Rajeh Hanaysha is currently a Senior Lecturer at DRB-HICOM University of Automotive Malaysia. He obtained his PhD majoring in Management from Universiti Utara Malaysia, Malaysia, in 2015, as well as an MSc (Management) from Universiti Utara Malaysia in 2011. He also received a Bachelor's degree in Marketing from Arab American University - Jenin, Palestine in 2008. To date, he has published more than 45 research articles in international journals and conferences. He has also received several awards for best research papers being presented at local and international conferences. His research interests include business management and marketing, in particular branding, consumer behaviour, social media marketing, CSR, business and product innovation, human resource practices, and business strategy. Jalal Rajeh Hanaysha can be contacted at: jalal. hanayshi@yahoo.com
\end{abstract}

